\title{
POLITICS OF THE NATION AND MADRASAH'S POLICY
}

\author{
Abd. Rahman Mas'ud \\ Head, Center for Research and Development of Religious Education \\ Jl. MH. Thamrin No. 6, JakartaPusat \\ Email:walisongos@yahoo.com
}

\begin{abstract}
Abstrak
Pendekatan sejarah dan politik digunakan demi pemahaman kemunculan kebijakan madrasah dalam sejarah Indonesia. Pendekatan ini dipercaya mampu memetakan hubungan antara politik dan kelahiran pendidikan madrasah. Dalam masa awal pembentukan, pendidikan madrasah tidak diakui oleh Belanda dalam masa pemerintahannya sebagai penjajah di Indonesia. Ini menghasilkan kurangnya aspirasi keagamaan dan pendidikan kaum Muslim terhadap pemerintahan Belanda. Kebijakanyang menentang madrasah mulai berubah dalam masa penjajahan Jepang yang memungkinkan kaum Muslim untuk berekspresi secara politik. Dalam era memasuki kemerdekaan, periode yang mengakomodasi ruang politik muncul dengan menyuarakan kaum Muslim, dengan bukti pembentukan Menteri Agama pada tanggal 3 Januari, 1946. Di masa inilah madrasah secara penuh dipayungi oleh kementerian agama. Hingga kini, madrasah dan pesantren belum diakui dalam sistem pedidikan nasional. Situasi ini berlangsung hingga tahun 1960an. Sejalannnya dengan masa orde baru, pihak pemerintah bersikap akomodatif terhadap aspirasi umat Islam, yang secara spesifik berhubungan dengan pendidikan. Maka dari itu pendidikan madrasah mulai masuk dan terintegrasi menjadi sistem pendidikan nasional. Pembentukan SKB Tiga Menteri pada tahun 1975 (kementerian agama, kementerian pendidikan dan kebudayaan, dan kementerian dalam negeri) dan pasal no. 2 tahun 1989 yang menyangkut sistem pendidikan nasional, mampu dilihat sebagai sebuah proses integrasi tahap awal. Madrasah adalah sekolah umum yang bersifat keislaman yang dibentuk oleh Kementerian Agama. Perihal ini berlangsung sampai terbentuknya pasal no. 20 tahun 2003 yang menyangkut sistem pendidikan nasional. Dalam periode ini, pendidikan madrasah dan sekolah umum memiliki level derajat yang sama.
\end{abstract}

Kata kunci: politik Negara, sistem pendidikan nasional, kebijakan madrasah

\section{Abstract}

Historical and political approaches were used to understand the birth of the madrasah's policy in throughout Indonesia's history. These approaches were considered to be able to map the relationship between politics and the birth of madrasah education policy. In the early period, when the nation was controlled by the Dutch colonial government, madrasah education was not included in the Dutch educational system. This was a result of the lack of fulfillment of religious and educational aspirations of Muslims by the Dutch government. Policy against madrasah began to change during the Japanese occupation where Islam began to gain a space for political expression. Entering post-independence, a political period known as the political accommodation emerged as the nation provided enough space for Islam to existed, marked by the establishment of the Ministry of Religious Affairs on January $3^{\text {rd }}$, 1946. This was when madrasah fell under the Ministry of Religious Affairs. Until this point, madrasah and pesantren were not included in the national education system. This situation continued

Naskah diterima 27 September 2013. Revisi pertama, 22 Oktober 2013. Revisi kedua, 10 November 2013 dan revisi terahir 3 Desember 2013. 
until the 1960s. During the New Order Regime, the government was very accommodative to Muslim aspirations, in particular those related to Islamic education. Thus madrasah education entered and was integrated into the national education system. The birth of SKB Tiga Menteri (Three Ministers decree) on 1975 (Minister of Religious Affairs, Minister of Education and Culture, and the Ministry of Home Affairs) and Law No. 2 Year 1989 concerning the national education system could be seen as the early integration of madrasah into the national education system. Madrasah is a public school distinctively of Islamic religion held by the Ministry of Religious Affairs. It was like this until the birth of Law No. 20 Year 2003 concering the National Education System. In this period, madrasah education is equivalent to education in public schools.

Keywords: Politics of the nation, national education syetem, madrasah's policy

\section{PRELIMINARY}

History says that religious educational institutions such as madrasah have proved selfexistence in developing the mentality of the nation. They are able to provide educational services to the fullest under any circumstances. Is it this service issue that became a problem for modern educational institutions such as schools?

For religious Indonesian people, madrasah education institutions are considered to contain two dimensions at once: religious and academic (general) elements. These two dimensions are like two sides of a coin as they cannot be separated from each other. If an institution is not able to fill these two needs, people will eventually abandon it. It is an indisputable fact presumably, that the community always questioned those two dimensions. Therefore, the existence of madrasah educational institutions is the right answer for these needs, as well as to be a counterweight institution in the fulfillment of the two-dimensional needs of Indonesian people: religious and academic. Colloquially, madrasah can be a shield to maintain the morale of students.

However, madrasah as an educational institution growing in the national, political and societal systems is certainly not facing simple issues. A survey conducted by the Basic EducationalProject(BEP) successfullyidentified several crucial issues related to the quality of madrasah: first, the weak prerequisites for the implementation of a quality education process; second, the insufficient facilities and resources that would otherwise enable improved access for communities to education; third, the educational bureaucracy of the Ministry of Religious Affairs is still very weak in terms of resources for policy formulation, planning and so on; and fourth, the existence of inequalities in educational development opportunities.

Those strategic issues, in addition to social-and political-based issues, cannot be separated from the long history of madrasah that has influenced education in Indonesia. Therefore, those strategic issues of madrasah education can be seen from the perspective of history and politics in the country in connection with Islam. Without looking at the historical and political aspects of the country, madrasah's policy including the regulation of madrasah cannot be understood in diachronic and synchronic ways. Why has madrasah become part of the national education system and aligned with the schools but does not look the same as schools? Although there are some qualified madrasah, why are some madrasah still faced with problem of quality? What causes the impression that madrasah is required to follow the general education system, given that madrasah were established a long time ago? In terms of society, why do some Muslim people still prefer school instead of madrasah? 


\section{Politics of the Dutch Colonialism, Japan's Occupation and Madrasah}

In the beginning of the 20th century, the Dutch colonial policy was known as ethical policy. The three basic principles of the policy were: educatie (education), emigratie (migration) and irrigatie (irrigation). ${ }^{1}$ The emergence of Ethical policy was influenced by the Liberal wing in the Netherlands which changed the direction of the Constitution of the Netherlands from conservatism to liberalism. In the field of education, the Constitution of 1848 guarantees free education for everyone in the Netherlands, which further has a derivative effect for education in the Dutch East Indies. ${ }^{2}$

Dutch colonial policy in education produces a dualism education system. The Dutch model education system, with its ethical politics ideas and education system, has existed in the community through such entities as Islamic education and Taman Siswa (Students Park) models. The Dutch colonial government chose the Dutch model for the general education system. An implication of this policy is that Islamic education institutions, including madrasah, are outside the general education system policy. Even according to some observers such as J.A. van der Chijs, an inspector of first indigenous education, the Islamic education system refused to conform to the general education system. Implementation and management of Islamic Education institutions including madrasah were carried out by Muslim leaders and Islamic organizations.

Policy towards Islamic education including madrasah cannot be separated from the politics of Dutch colonial government against Islam. It is Christiaan Snouck Hurgronje who submitted

${ }^{1}$ MC. Ricklefs, 2005. Sejarah Indonesia Modern. Yogyakarta: Gadjahmada University, h. 228

${ }^{2}$ Yudi Latief. 2005. Intelegensia Muslim dan Kuasa: Generasi Muslim Abad ke-20. Bandung: Mizan, h. 78

${ }^{3}$ Karel A. Steenbrink, 1994. Pesantren, Madrasah, Sekolah: Pendidikan Islam dalam KUrun Modern. Jakarta: LP3ES. h. 26-82 policy recommendations toward Islam in a term called "splitsingstheorie". This theory divides Islam into two parts: the first, Islam as a religious nature; and the second, Islam as a political nature. While the colonial government had to respect the first aspect of the Muslim life, they can not tolerate the second. ${ }^{4}$ Snouck Hurgronje himself supported education models that are elitist and European in style with Dutch as the language of instruction and with the goal of controlling Islamic fanaticism. ${ }^{5}$

The description above shows that the Dutch colonial government with its ethical politics did not include the madrasah education system into the public education system. Although there was no regulation, the implementation of madrasah education was carried out by Muslim leaders and Islamic organizations in various regions in Indonesia.

Policy toward madrasah began to get fresh air with the policy of the Japanese occupation that gave Islam a space for political expression. The Japanese government improved the position of Islam and gave it social prestige and implicitly political prestige. The Japanese government entrusted the post of head of the religious affairs' office to the people of Indonesia. The Japanese government established the Islamic organization Masjumi with its Islamic identity. Masjumi leaders became government employees in both central and local administrations who were in charge of Islamic matters. ${ }^{6}$

\section{Ministry of Religious Affairs and the Law No. 4 of 1950 jo.No 121954}

After the proclamation of independence on August 17, 1945, Komite Nasional Indonesia Pusat (the Central Indonesian National Committee, KNIP), during its meeting on 11 November 1945, accepted acclamation

${ }^{4}$ Yudi Latief, op. cit., h. 82-83

${ }^{5}$ M.C. Ricklef. op. cit., h. 236

${ }^{6}$ Harry J. Benda. 1985. Bulan Sabit dan Matahari Terbit: Islam Indonesia pada Masa Pendudukan Jepang. Jakarta: Pustaka Jaya. h. 234-244 
proposal of KH Abu Dardiri, M. Saleh Suaidi and M. Sukoso Wirjosaputro which was further supported by Mohammad Natsir, Dr. Muwardi, Dr. Marzuki Mahdi, N. Kartosudarmo and others who suggested that in Indonesia, as an independent country, religious matters should be taken care of exclusively by a separate ministry, the Ministry of Religious Affairs. President Soekarno motioned to the vice president Mohammad Hatta, who then stood up and spontaneously stated: "the existence of the Ministry of Religious Affairs has gotten the government's attention".

As a realization of the government's concern, the government issued Determination No. 1/SD on January 3, 1946, which includes: the President of the Republic of Indonesia considering the proposal of the Prime Minister and the Central Indonesian National Committee workers, decided: "Holding the Ministry of Religious Affairs". The government's determination on the basis of the proposal of Badan Pekerja Komite Nasional Indonesia Pusat (the Working Committee of the Central Indonesian National, BPKNIP) on December 27, 1945 was that Kementerian Pendidikan Pengajaran dan Kebudayaan (the Ministry of Education and Culture, PP and K) would seek renewal in accordance with Education and Teaching in line with a new Basic Plan for Education Effort which concerned 10 issues, including issues of religious teaching, Madrasah and Pesantren. This BPKNIP suggestion was realized after the Minister of PP and $\mathrm{K}$ formed a Committee of Inquiry Teaching RI.

Approximately three and a half months after the establishment, the Ministry of Religious Affairs issued an edict numbered 2 on 23 April 1946 which states that: 1) Shumuka in the era of Japan, including the President's power, becomes the Regional Religious Affairs Bureau, which will be under the Ministry of Religious Affairs, 2) The rights to lift Landraad (now named the District Court), the Chairman and Members of Religious Landraad formerly in the hands of the President, are then submitted to the Ministry of Religious Affairs, and 3) The right to appoint Mosque Chief, formerly in the hands of the Regent, is then submitted to the Ministry of Religious Affairs.

Then on 2 April 1950 in Yogyakarta Law No.4 Year 1950 was created concerning the basics of education and teaching in schools, which was applied to the whole of Indonesia on March 12, 1954 by Law No.12 Year 1954. The law does not explicitly regulate articles about madrasah. Even in Article 2 paragraph (1) and (2) of the Act says: "This Act does not apply to education and teaching in religious schools and public education" and "education and teaching in religious schools and the education community respectively are stipulated in other laws". That is, the law stated that the madrasah and pesantren are not included in the national education system. This situation continued throughout the rest of the 1950s and continued even in the 1960s when the politics of the nation were in the period of Guided Democracy (1960-1966). However, the law regulates religious education in public schools as stated in Article 20 paragraph (1) and paragraph (2). There are two important points of the law for Muslims. The first is religious education as part of national education. The second is graduate students from religious schools which are recognized by the Ministry of Religious Affairs as having met the compulsory study.

Those laws were born at the beginning of the period of Liberal Democracy (19501959). 1950-1959 was the period when de facto Indonesia became an independent state. This period canalso be regarded as a period of conflict between the parties. Through the results of the 1955 election, political Islam's gait temporarily failed. ${ }^{7}$ Although Islamist groups were still strong in the regional level, at the national level political progress of Islam was stalled due to election results 1955, hence the interest and energy of Islamic leaders focused on efforts to strengthen themselves and on issues such as

${ }^{7}$ B.J. Boland. 1985. Pergumulan Islam di Indonesia: 19451972. Jakarta: Grafiti Press. h. 48 
education, publishing books and developing activities of the Ministry of Religious Affairs. ${ }^{8}$ The alance of power of political parties gave opportunities for Soekarno to intervene, so on July 5, 1959 he issued a decree back to the 1945 Constitution. Soekarno judged that liberal democracy had spawned conflict continuously and was not in accordance with Indonesian culture. In returning to the 1945 Constitution, sukarno had great power in leading the nation. the decree was opposed mainly by Masjumi ( $2^{\text {nd }}$ largest party based elections 1955), the leader of the Socialist Party of Indonesia. Mohammad Hatta himself resigned from his position as Vice President of the Republic of Indonesia.

Related to Decree 1959, Sukarno was supported by NU ( $3^{\text {rd }}$ winner party) and PKI ( $4^{\text {th }}$ winner party) in addition to the army and his party, PNI ( $1^{\text {st }}$ winner party). To gain support among Muslims, Soekarno accommodated Muslim aspirations. MPRS Decree 1960 was a very important cornerstone in the development of religious education, as MPRS Decree 1960 confirms that the government conducts religious education from low-level education to higher education and supports the development of religious educational institutions. Although it is still affirmed that education is only an option (not mandatory), the Ministry of Religious Affairs in this period established education for religious teachers and developed Islamic higher education. Interestingly, on the other hand the Ministry of Education and Culture during this period confirmed that national education should give birth to a new human being, namely an Indonesian socialist man did not hold religion as a public value that must be grown.

\section{Politics of New Order and Three Minister Decree of 1975}

The New Order government in the early days became a new hope for Muslims and strongly supported the aspirations of Muslims.

${ }^{8}$ Ibid., h. 89
MPRS Decree No. II/MPRS/1960, which then was updated with MPRS Decree No. MPRS XXVII/MPRS/1966, was a very important policy related to religious education. The New Order was very accommodative to Muslim aspirations toward religious education as part of the dekomunisasi. However, the New Order was actively modernizing religious education and madrasah so that they were in line with the New Order agenda: eliminating social inequality and promoting national development and national integration.

It is interesting to observe that Presidential Decree No.34 of 1972, which was then reinforced by Presidential Directive 15 of 1974, illustrates a strong tension in the relationship between madrasah and national education. This Presidential Decree and Presidential Directive is also seen by some Muslims as a maneuver to ignore the role and benefits of madrasah as well as debilitating madrasah and alienating madrasah from national education. The government then took over operational policy in relation to madrasah to improve the quality of madrasah education. In line with these efforts, on March 24, 1975 a policy of Joint Decree (SKB) of 3 Ministers was issued, which was signed by the Minister of Religious Affairs (Prof. Dr. Mukti Ali), Minister of Education and Culture (TNI Letjen. Dr. Teuku Sharif Thayeb) and Minister of Home Affairs (TNI Jend. Purn. Amir Machmud).

Joint Decree of 3 Minister includes some dictum, namely: (1) Madrasah is the institution that made the Islamic religious class a basic class which is given at least $30 \%$ in addition to general class, (2) Madrasah includes 3 levels: MI level with Elementary School, MTs level with Junior High School, MA level with Senior High School, (3) The purpose and objective of quality improvement of education in madrasah is that the general subjects in the madrasah reach the same level as those in Public Schools, so that: a) the Madrasah diploma can have the same value as the Public School diploma, b) Madrasah graduates can proceed to the upper 
level of the Public Schools, and c) Madrasah Students can move to the same level Public Schools. Related to Madrasah financing, the Three Ministers Decree made clear that in addition to the budget burden on the Ministry of Religious Affairs, it should also be borne by the Ministry of Education and Culture and the Ministry of Home Affairs.

Three Ministers decree of 1975 is one of the milestones in the integration of Islamic education into mainstream national education. Furthermore, this ministerial policy is essentially the first step for the reintegration of religious sciences and general sciences in Islamic educational institutions.

In the Three Ministers Decree, it is explicitly stated that madrasah are educational institutions that make Islamic religious classes basic classes, which are given at least 30 percent in addition to general classes. The intent and purpose of improving the quality of education in madrasah is centralized at the level of general subjects to match the level of general subjects in public schools.

In the early stages after the Three Ministers Decree, the Ministry of Religious Affairs developed the curriculum of 1976 and began intensively enforcing it starting in 1978. To enhance this curriculum of 1976, the Two Ministers Decree: Minister of Education and Culture and the Minister of Religious Affairs in 1984 on Standardization for Curriculum of Public Schools and Curriculum of Madrasah, which included quality equation of madrasah graduates that can continue their education to a higher level public schools. This was what gave birth to the 1984 Curriculum for Madrasah. Madrasah curriculum in 1984 reinforced the integration of madrasah into the national education system. In the Madrasah curriculum of 1984, there was no difference with the regular school curriculum; there was just more religious education.

With the birth of the Madrasah curriculum of 1984, madrasah faced a dilemma between the need to maintain an identity of religious education and implementing general education. In the vortex of this policy, madrasah faced an identity crisis. The responsibility toward general classes was so great that it could eliminate the mission, substance and character of Islamic education itself.

Following up on Two Ministers Decree, curriculum for madrasah of 1984 was created as stipulated in the Decree of the Minister of Religious Affairs No. 99 of 1984 for madrasah ibtidaiyah, No. 100 of 1984 for madrasah tsanawiyah, and No. 101 of 1984 for madrasah aliyah. Thus the 1984 curriculum refers to the Three Ministers Decree and Two Ministers Decree, both in the composition program, goals, as well as study materials and lessons.

Specifically for the Curriculum of MI and MTs in 1984, the adjustments and improvements of its program structure, namely through the Minister of Religious Affairs Decree No. 45 of 1987 about the Adjustment on Structure of Curriculum Program of MIN and MTsN and applied until the arrival of the 1994 curriculum.

Apart from the positive side of the number of policies carried out against madrasah, from Three Minister Decree of 1975 to the imposition of 1984 curriculum and its perfection to the level of MI / MTs in 1987, as an educational institution that from the beginning was identical of its Islamic identity, madrasah remained exposed to difficult choices. First, on the one hand they had to maintain the quality of religious education that was their trademark; secondly, on the other hand, they were required to provide good-quality public education so that they could be aligned with the public schools. This was obviously a very heavy burden borne by the madrasah.

The Decree of the Minister of Religious Affairs No. 101 of 1984 concerning the curriculum of Madrasah Aliyah mentioned that the composition of Madrasah Aliyah curriculum consists of core courses and optional courses. The core program includes religious education and general basic education. The core program of religious education which is the identity 
of madrasah included subjects about quran hadis, aqidah akhlak, fiqh, Islamic history and civilization, and the Arabic language. Besides the core program, there was an optional program which consisted of options A and B. Optional program A was religious sciences, while optional program B was the service of religion.

The religious sciences program was aimed to prepare students who would continue their education to higher education courses that examined the historical sciences, sciences of Ushuluddin, science of propaganda, tarbiyah Islamiyah, manners and so on. Curriculum load that must be passed by madrasah aliyah students of the religious sciences program was 240 credits in total, consisting of 160 core courses and 80 optional courses. Of 240 credits that can be said to lead to the identity of madrasah aliyah totaling 56 credits of religious education and 56 credits of science education development.

In order to meet the need for experts in the field of Islamic religion in accordance with the demands of national development efforts, the quality of education in madrasah aliyah needed to be improved. One of the attempts was opening a special program at the madrasah aliyah of the choice of religious sciences, namely Madrasah Aliyah Program Khusus (Madrasah Aliyah Special Program, MAPK). Madrasah Aliyah Special Program was first held in 1987 on the basis of the implementation of the Decree of the Minister of Religious Affairs No. 73 in 1987. The implementation was technically was regulated by the Decree of the General Director of Islamic Institutions Development (now General Director of Islamic Education) No. 47/E/87 on Madrasah Aliyah Special Programs Implementation Guidelines and Center Coordination Team Formation.

The emergence of MAPK is actually a response to the reduced religious quality of madrasah aliyah, as a result of the Joint Decree (SKB) of Three Ministers that the point is that the cross-departmental made a concerted effort to improve the quality of madrasah education so that the quality of general knowledge of madrasah students can reach the same levels as the equal public schools. With such a purpose, the Decree was a good attempt in improving the quality of MA. However, the ratio of 70 percent for general education and 30 percent for religious education, eventually did not lift the quality of madrassa but made the religious foundation of madrasah worse off.

With the opening of MAPK in the Madrasah Aliyah program, the concerns of the majority of Muslims concerning its reduced religious program in Madrasah Aliyah could be solved. The emergence of MAPK has brought improvements in the quantity and quality of madrasah to the national education system. Eventually MAPK was renamed to Madrasah Aliyah Keagamaan which is the realization of Law No. 2 of 1989.

\section{Law No. 2 of 1989 and Religious Identity of Madrasah}

Continuing the policy of development politics, the New Order since 1989 began to be friendly towards Muslims. Moreover, a number of new Muslim intellectuals were with new paradigm of the new Islamic intellectual. Act No.2 of 1989 on National Education System is one of New Order's product policies in the field of education.

Because the Muslims demanded that religion and religious education should be an important element in national education, after a long negotiation and debate, the Ministry of Education and Culture put faith and piety as part of the national education goals and placed religious education as a very important part in the national education system. Previous law never made religious attitudes as national education goals.

In Law No. 21989 Article 10 paragraph (1) it is mentioned that "education is carried out through two (2) channels, namely a school education track and a non-school education track". It is further mentioned in Article 10 paragraph (2) and (3) that: "the school 
education track is organized in schools through teaching and learning activities which are tiered and sustainable" and "the non-school education track is organized outside school through teaching and learning activities that may not be hierarchical and continuous ". The type of education that is included in the school education track consists of general education, vocational education, special education, service education, religious education, academic education and professional education.

Based on the educational track as in Law No. 2, the position of madrasah is in the school education track. However, with regards to the kind of education as stated in Law No. 2 Article 11 paragraph (1), is madrasah included in general education or religious education. The word "madrasah" is explicitly listed in the Indonesian Government Regulation No. 28 Year 1990 on Basic Education Article 4 paragraph (3), reading: "Elementary and Junior High Schools, distinctively of Islam, organized by the Ministry of Religious Affairs, respectively called Madrasah Ibtidaiyah, Madrasah Tsanawiyah". However, in the Indonesian Government Regulation No. 29 Year 1990 on Senior High School Education, "Madrasah Aliyah" is not specifically mentioned, but instead there is the term "religious high school education" which in paragraph 4 is called "Religious School" as a form of high school education.

The word "madrasah" is also mentioned in the Decree of the Minister of Education and Culture of the Republic of Indonesia Number 0487/U/1992 about Elementary School in article 1, paragraph (2) which reads: "Madrasah Ibtidaiyah is an Elementary School that is distinctively religious organized by the Ministry of Religious Affairs", and in Article 3 paragraph (1) which reads: "The form of education for children aged 6-12 years with a 6 year old learning consists of Elementary School, Small Elementary School, Tutors Elementary School, Integrated Elementary School and Madrasah Ibtidaiyah". The word "madrasah" is also included in the Decree of the Minister of Education and Culture of the
Republic of Indonesia Number 054/U/1993 on Junior High School in article 1, paragraph (5), which reads: "Madrasah Tsanawiyah is a Junior High School distinctively of Islamic origin organized by the Ministry of Religious Affairs ", and in Article 3 paragraph (1) which reads:" The form of the basic educational unit which organizes the education program after three years of elementary school consists of junior high school and Madrasah Tsanawiyah. Unlike in Government Regulation No. 29 Year 1990 on Senior High School Education, Minister of Education and Culture of the Republic of Indonesia Number 0489/U/1992 on Senior High Schools explicitly mentions the word "Madrasah Aliyah" which is defined distinctively as Islamic Senior High Schools organized by the Ministry of Religious Affairs as expressed in article 1, paragraph (6).

Government Regulations and Decree of the Minister of Education and Culture associated with madrasah, and the Minister of Religious Affairs set decisions about madrasah. First there is the Decree of the Minister of Religious Affairs of the Republic of Indonesia Number 368 of 1993 on Madrasah Ibtidaiyah. Second there is the Decree of the Minister of Religious Affairs of the Republic of Indonesia Number 369 of 1993 on Madrasah Tsanawiyah. Third there is the Decree of the Minister of Religious Affairs of the Republic of Indonesia Number 370 of 1993 on Madrasah Aliyah, and fourth there is the Minister of Religious Affairs of the Republic of Indonesia Decree No. 371 of 1993 on Madrasah Aliyah Keagamaan.

With these regulations, madrasah institutionally is integrated into the national education system. Madrasah are distinctively Islamic public schools held by the Ministry of Religious Affairs. What is a characteristic of Islam? Characteristics of Islam are manifested in the form of the development of study materials and lessons of Islamic religious education, the creation of a religious atmosphere, and the inspiration for all study materials and lessons with the teachings of Islam. 
Related to the characteristics of Islam in madrasah, the Minister of Religious Affairs set decisions about madrasah curriculum. Firstthere is the Decree of the Minister of Religious Affairs of the Republic of Indonesia Number 372 of 1993 on the Basic Education curriculum distinctively Islam. Second there is the Decree of the Minister of Religious Affairs of the Republic of Indonesia Number 372 of 1993 on curriculum of Madrasah Aliyah, and third there is the Decree of the Minister of Religious Affairs of the Republic of Indonesia Number 374 of 1993 on the curriculum of Madrasah Aliyah Keagamaan.

\section{Period of Reformation, Law No. 20 of 2003 and Identity of Madrasah}

Law No. 20 of 2003 Article 3 states that the national education aims to develop the potential of learners in order to become a man of faith and instill a fear of God Almighty, as well as become a noble, healthy, knowledgeable, skilled, creative, independent and responsible person, and become a democratic citizen. Act No. 20 of 2003 Article 17 and Article 18 confirms the same recognition between MI with SD, MTs with SMP, MA with SMA, and MAK with SMK.

If Act 2 of 1989 was momentum for madrasah to integrate into the national education system, then No. 20 of 2003 became a starting point to follow up the momentum. The following description will address the case on the issue of strengthening religion in madrasah aliyah after Act No. 2 of 1989 and Act No. 20 of 2003.

In Act No. 2 of 1989 Article 11 paragraph (1), it is stated that the type of education that is included in school education track consists of general education, vocational education, special education, service education, religious education, academic education, and professional education. This provision does not mention whether the madrasah aliyah is included in general education or religious education. Still in Government Regulation No. 29 Year 1990 on senior high education and the Decree of the Minister of Education and Culture No. 0489/U/1992 about senior high school, Madrasah Aliyah is a distinctively Islamic public high school organized by the Ministry of Religious Affairs. That is, madrasah aliyah is included as a type of general education and not a kind of religious education. This can be seen from the contents of MA curriculum which consist of a few religious subjects: 6 credits for quran hadith, 2 for aqidah akhlak, 2 for figh and 1 for Islamic cultural history. In other words, religious programs in madrasah aliyah experienced marginalization and also raised issues concerning - borrowing the term of Azyumardi Azra -"identity" or "distinction" of Islam in madrasah after Act No. 2 of 1989.

In order to comply with the Law No. 2 of 1989 on National Education System, the Minister of Religious Affairs issued decision No. 371 of 1993 on Madrasah Aliyah Keagamaan which renamed MAPK to Madrasah Aliyah Keagamaan (MAK). This was then followed by the Circular Issuance of the General Director of Islamic Guideline No. E.IV/PP.00/A.2/445/94 on structuring Madrasah Aliyah, which includes the curriculum structure of MAK.

There are two main points on the change of MAPK to MAK. They are: first, MAK is no longer the flagship school that was founded on a limited basis, but MAK is held by the government. The government gives the opportunity to the people to establish MAK as long as its requirements are met; second, Curriculum Content Standards of MAK lead to more specialized religious sciences while reducing some common materials that exist in the standard curriculum of MAPK.

However, the change from MAPK to MAK still brought up the same issue of religious sciences education quality, in order for the spirit of education and the education system of MAPK and MAK to have no difference, namely: First, a rigorous selection system and a requirement of high academic abilities (pure grade of religious subjects of at least 7 , grades of math and English language of at least 6, and preferably ranks 1 to 10 in the class); Second, a 
system of pesantren (Islamic Boarding School), where all the students have to stay in a lodge / hostel under the supervision of Trustees for 24 hours; Third, language, where for all religious subjects, handbooks and references, as well as evaluation tests are in Arabic.

Educational laws continue to evolve in line with the spirit of this nation to make changes for the better in the two types of education. Thus, a national education system law was created, namely Law No. 20 of 2003, which was known as the Education System Law. Changes in this education law also require a change in MAK institution. This is because the National Education Law does not use the term Madrasah Aliyah Keagamaan. What precisely the Law means when using the term of MAK is Madrasah Aliyah Kejuruan, while at the Intermediate level of Madrasah Aliyah, Education Law mentions 4 programs / departments namely: Natural Sciences Program, Social Sciences Program, Religious Programs, and Language Program.

As a consequence of changes in this law, the Ministry of Religious Affairs must change the Madrasah Aliyah Keagamaan (MAK) to Religious ProgramsinMA.Thus the Circular of the Director General of the Islamic Educational NO: DJII.1 / PP.00/ED/681/2007 on the Implementation of Content Standards of MA was created, which among other things contains a change of MAK to Religious Programs and Language Program. In addition to institutional changes of MAK to Religious Programs, this Circular also includes curriculum content standards for Religious Programs. The consequences of these changes are that institutionally they could no longer be questioned, and students have to follow the national curriculum standards and tests set by Badan Standar Nasional Pendidikan (National Education Standards Agency, BSNP).

In contrast with the change from MAPK into MAK, substantially there is still the red thread, the change from MAK to Religious Programs remains a crucial issue for the quality of religious programs. First there is the system of admissions. According to the MA curriculum content standards of all programs, including religious programs, the major selection is carried out in class XI. Through the curriculum of MAK, major selection occurs after a rigorous selection process. Second, the Final exam (National Examination and Testing of Madrasah) made by BSNP for religious subjects uses the Indonesian language, despite the fact that in MAK curriculum the language of instruction, textbooks, and test evaluation of religious subjects is Arabic. Third there is the allocation of learning time. Time allocation set by the government for religious programs is same with other programs in MA. However, the MAK implementations of learning consist of learning in the morning, afternoon tutorials, and studying at night, as well as all students living in dormitories or attending boarding school.

Thus a change of MAK into a Religious Program has two opposing sides. One side brings positive change concering the legal status of the institution, but on the other hand there is a set back in terms of quality. In other words, this change is the return of MAK to the program A1, which was previously MA 1980s until the 1990s.

"Religious Programs" are different from "Religious Education". Religious education is generally held by the public to be an educational embodiment of, by, and for the community. Long before Indonesia's independence, religious universities had already developed. As the cultural roots of the nation, religion is thought of as an integral part of education. Religious education is also growing due to religious education subjects who rated face limitations. Most people had additional religious education in the home, house of worship, or in associations which later evolved into the unit or program of formal, non-formal or informal religious education. Historically, the existence of community-based religious education was important in the development of learning communities, particularly as it came from the aspirations of the community that reflected real education needs. 
In Government Regulation No. 55 of 2007 on Education of Religion and Religious Education, it is stated that religious education is an education that prepares students to perform a role that demands mastery of knowledge about religion and / or having expert knowledge of religion and practicing their religion. Thus, religious education aims to form students who understand and practice the values of their religion and / or to be religious experts who are insightful, critical, creative, innovative and dynamic in the context of the intellectual life of the nation, who believe in and fear Allah and who are noble.

Referring to this definition, there is a fundamental difference between religious programs and religious education. A "religious program" is part of an educational unit while "religious education" is the path and the type of education that offers religious teaching with the goal of fostering prospective science experts of religion (Islam), who not only form a religious personality in themselves, but can also provide religious guidance to others. In the context of Islam, religious education was occurs in diniyah education and boarding school.

Tafaquh fi al-ddin oriented education is included in the religious education category. Nevertheless, religious programs must remain in Islamic education, on any educational unit it is in. One attempt to revive religious programs in kinds of public education such as madrasah aliyah is to maintain the spirit of MAPK/MAK in religious programs in MA.

Various attempts have indeed been made by the Ministry of Religious Affairs to maintain and seek solutions for the development of this institution. However, in the end the Ministry of Religious Affairs "resigned" on option to restore MAPK in Religion programs (A1) (religious program) that long ago was in Madrasah Aliyah.

Currently there is anxiety again that religious spirit is weakening in madrasah aliyah. The anxiety does not have to do with the change of MAPK to Religious Programs in
MA, as it is the most realistic option considered by policy makers to obtain legal powers in legislation.

Instead, the anxiety is about the attitude and set back actions of the Ministry of Religious Affairs which change the MAPK to a Religious Program. This is not only related to names and institutions, but also the whole system and its curriculum have become like Program A1 in the past.

The Ministry of Religious Affairs is expected to take action to maintain the good side of the MAPK while making new changes which are favorable for the development of Islamic religious education. In the case of MAPK, the Ministry of Religious Affairs is expected to maintain the pattern and the education system of MAPK/MAK on Religious Programs that previously held MAK, although the name and institutional structure has changed. The Ministry is also expected to provide adequate support in regard to the performance and quality of output produced over the years. As for other MA which want to establish regular Religious programs in accordance with national standards alone, this is not a problem.

The existence of Madrasah Aliyah, which still hold religious programs modeled on MAPK/MAK, can be a consideration in reviving the MAPK/MAK program by transplanting it to Madrasah Aliyah. The most reasonable way is to revoke the Circular of Director General of Islamic Education No. DJII.1/ PP.00/ED/681/2007 on the Implementation of Content Standards of MA, which among other things contains a change of MAK to Religious Programs, and publishing KMA about religious programs at an intermediate level which consists of the restoration of system and curriculum of MAPK/MAK.

\section{CLOSING}

The description above implies that the existence of madrasah institutions cannot be separated from the political context of the country being run. As a product of national policy, regulation of Islamic education in general and madrasah institutions in particular 
have experienced a flux and flow depending on the politics of the nation. When Muslims are on the rise then madrasah and its regulation have experienced the same thing. Vice versa, madrasah and its regulations on the decline result from a receding condition of Muslims. In the future, there should be a negotiation of politics with the outside system which has an equal position, unlike today when madrasah stakeholders of are helpless. There are many regulations in connection with madrasah but there is no regulation underneath.[]

\section{REFERENCES}

Boland, B.J. (1985): Pergumulan Islam di Indonesia 1945-1972. Jakarta, PT Grafiti Pers.

Benda, Harry, J. (1985): Bulan Sabit dan Matahari Terbit: Islam Indonesia Pada Masa Pendudukan Jepang. Jakarta, Pustaka Jaya.

Compilation of Regulation Legislation of Islamic Education in Public Schools (1998): the Ministry of Religious Affairs of RI, Directorate General of Islamic Institutions Development. 1998/1999
Compilation of Regulation Legislation of Religious Education (1994): Regional Office of the Ministry of Religious Affairs in West Java Province

Latif, Yudi (2005): Intelegensia Muslim dan Kuasa: Genealogi Intelegensia Muslim Indonesia Abad ke-20. Bandung, Mizan.

Ricklefs, M.C. (2005): Sejarah Indonesia Modern. Yogyakarta, Gadjah Mada University Press.

Steenbrink, Karel A. (1994): Pesantren, Madrasah, Sekolah: Pendidikan Islam dalam Kurun Moderen. Jakarta, LP3ES.

Woodward, Mark R (ed) (1998): Jalan Baru Islam: Memetakan Paradigma Mutakhir Islam Indonesia. Bandung, Mizan. 